\title{
表面活性物質ガ培養上皮組織二及ボス 影響二就于
}

\author{
京都帝國大學醫學部產婦人科學教室 (主任 岡林教授) \\ 京都帝國大學醫學 部微生物學教室 (主任 木村教授)
}

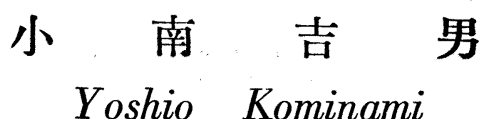

(昭和11年12月 21 日受付)

\section{【内 容 抄 錄】}

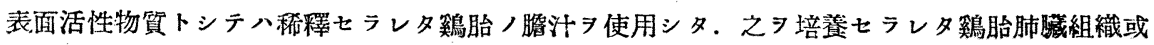

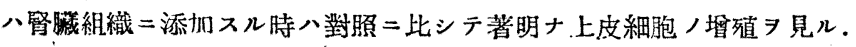

\section{目次}

第 1 章. 緒 䓂

第 2 章 穓驗材料及筫驗方法

第 3 管 贯驗成續

1. 珹長計測成績

2. 組織學的所見
3. 培地液化二就テ

第 4 章 總括及考按

第 5 草 結 諭

主要文献

附圆說明

\section{第 I 章 緒言}

惡性腫境 發生原因トシテ之迄提示七ラレタモノ八誠二多忮多端デアルカ，Bauer(1)八之 フ統一的二觀察シデ, 惡性腫瘍, 殊二癌，發生原因八體液，表面張力低下デゲラウト言ツタ

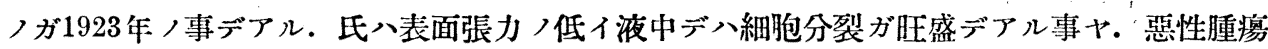
ノ抽出液, 表面张力八低倳ヤ, 或八各種, 催癌物質, 例へバ Anilin, Teer 及乳酸等八化

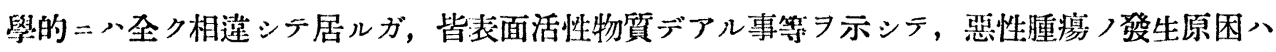
體液, 表面張力低下デアルト言ツタ.ソ/後今日二至儿迄10年餘リノ間 =, 表面張力ト惡性

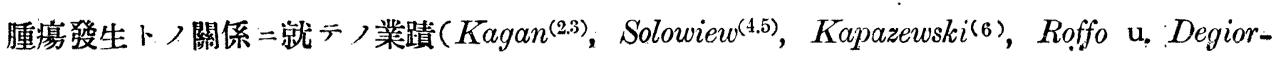
$g^{i(7)}$, Guthman u. Frühauf ${ }^{(8)}$, Rabiner ${ }^{(9)}$, 荒川 ${ }^{(10)}$, 飯野(11), 松岡(12), 菊池及河西(13), 等）八尠クナイガ, Katzenstein u. Knake $e^{(14)}$, 八培養組織, 生トシテ膵㖪組織〉培養七ラレ

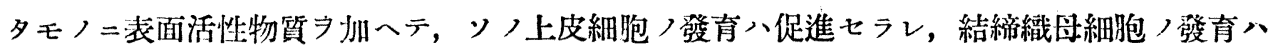

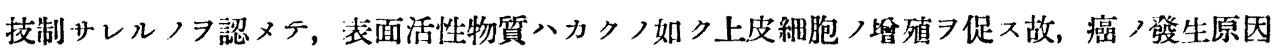
トナリ得ル事ヨ示シタ、ソコデ私八百尺竿頭一步ヨ進メ, 表面活性物質ガ培養七ラレタ肺臟 及腎臓 =及ボス作用フ知ラウトシテ本實驗二着手シタノデアル. 
Fischer u. Laser ${ }^{(15)}$ 並=辻(16) 八他 八立場カラ表面活性物質ガ培食縕織 $=$ 及ボ 大作用 7 研 究シテ居ル. 即チ氏等つ見解二從フトMedium, 表面張力ガ低下スレバ細胞瞙, 透過性が 增加スル故二, 今迄生體染色ノ不可能テアツタ細胞ガ生體染色可能ニナリハシナイカトイフ 豫想ノ下 $=$ 行ハレタ興味アル實驗デアルガ，余八本報告 $=$ 於テハ都合 $=ヨ ツ テ$ 此 點 $=$ 八觸 レナイ

\section{第 2 童 實驗材料及實驗方法}

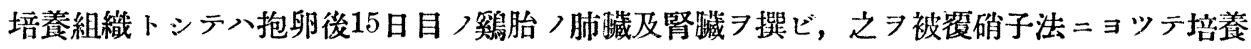

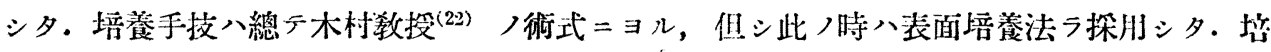

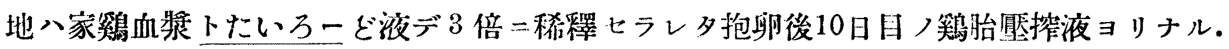

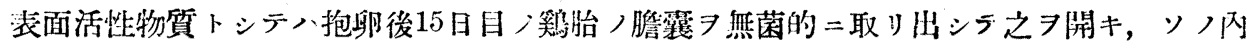

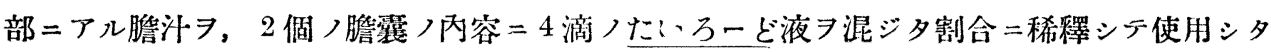
ガ, コノ濃度ノ膽汁デ八細胞ノ發育八全ク見ラレナカツタ故, 以上ノたいろ一に゙液デ稀釋シ

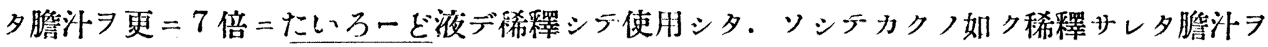
1 滴培養卜同時二肺歲組織片或八腎獩組織片二添加シタノデアル。カクシテソノ成長ヨ計测

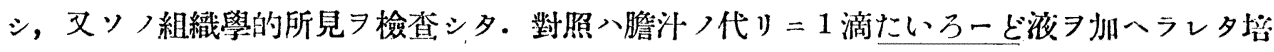
養組織デアル。培養後48時間 $\ni$ 檢查シタ. 比較成長價 ( $\frac{\text { 現面皘一原面皘 }}{\text { 面原積 }}$ ) 知ルニ八Edinger's Vertikaler Projektionsapparat デ掊養組織ノ投射像シ畫キ，Planimeter デソノ面積习計测シテ之ヨ知リ，組織學的 所見ヨ檢スルニ八, 先ヅ新鮮ナ狀態デ檢査シが後 Fischer ノ手技=從ツテ Totalpräpart 卜 シテへまときしりんデ染色シテ檢鏡シタ・ソシテ本篇デ私ガ比較成長價习計测シタノ八新生 上皮紐咆デアツテ，結締織母細胞樣ノ細胞ノ比較成辰價八計测シナカツタ・ソレ八新生上皮 緗胞八膜狀 =成長シテ來ルカラソノ投射像八正推二紙上=畫ク事ガ出來ルガ, 結締織母細胞 樣ノモノデハ左樣ナ譯＝行カナイカラデアル。ソノ代リ結締織母細胞樣ノ緗胞/新生ノ程度 ⼀, +, H, 卅, デ大略ヨ示ス事トシタ. 又液化サレタ培地モソ/投射面積シ同樣二測定 シデ, 之ョ原面積デ除シタモノフ算出シタ.

\section{第 3 章 實 驗 成 績}

\section{I 成 長 計 測 成 績}

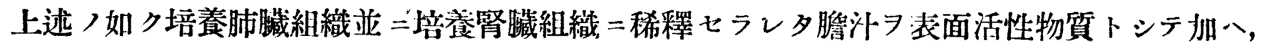
ソ’此較成長價 ヨ計測スルト次二表示スル樣ナ成績ニナツタ・表ニ示ナレタ值八全テ平均值 
デアツテ数热八膽汁，代リニたいろーど液ヨ 1 滴加へタモノデアル．培地液化二於イテハ行 ヨ改メテ記载スル故, 茲デハ暫ク之二レ觸ナイ。

\begin{tabular}{|c|c|c|c|c|}
\hline & , & $\begin{array}{l}\text { 上皮細胞比較成長 } \\
\text { 傮/本均 }\end{array}$ & $\begin{array}{l}\text { 結締織扵細胞 } \\
\text { 發育程度 }\end{array}$ & $\begin{array}{l}\text { 培地液化面積 } \\
\text { 原 平均 面 積 }\end{array}$ \\
\hline 留 & 對 照 & 1.9 & + & 2.9 \\
\hline 筬 & 試 羷. 列 & 2.4 & + & 2.3 \\
\hline 肺 & 對 炤 & 0.6 & + & 22.5 \\
\hline 贜 & 試 驗 列 & 1.8 & $H$ & 3.4 \\
\hline
\end{tabular}

コノ成績カラ見ルト Katzenstein u. Knake ノ言ツタ樣二, 表面活性物質ノ加ヘテアル試 驗列デ八上皮細胞ノ發有八對照ヨリモ遥二旺盛デアル．シカシ結締織母細胞，發育八表面活

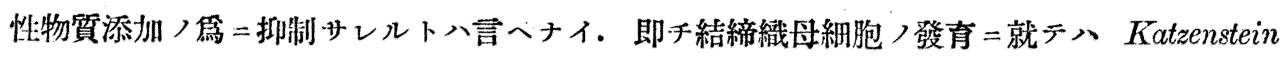
u. Knake ノ成績ト・一致シナカツタ. Katzenstein u. Knake ノ云フ所二從フト，對照デハ 新生細胞ハ結締織母細胞許リデアルガ, 表面活性物質 育スル故, カクシテ上皮細胞, 純墫養ガ獲得七ラレルト言フガ, 私ハソノ樣二著明ナ成績八得 ラレナカツタ。但シ氏等卜私卜八筫驗材料ガ相違シテ居ルトイフ事モ考慮ニ入レネバナラメ.

\section{2 組織學的所見}

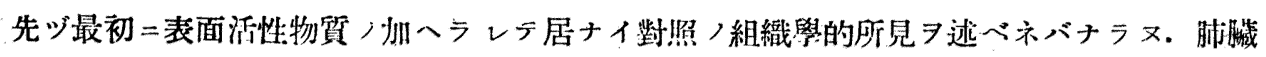
組織或八腎藏組織 シテ上皮細胞八原組織，周圍 =膜狀或八舌狀二發育シソノ配列 = 敷石狀デ細胞 形八多角

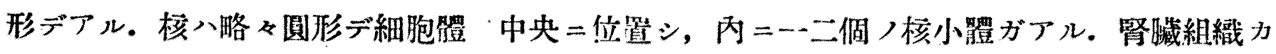
ラ墢育シテ來ル上皮細胞八一般 =原形質加喑ク. 殊=暗イ原形質 7 有スル上皮細狍卜比較的 明イ原形質习持ツモノトノ 2 種ノ上皮細胞ガ見ラレソレゾレ玟狀丈、楔形ヨナシテ分布シテ 居ル. 特二暗イ原形質习有スル方ノ上皮細胞 ときしん=濃染スル顆粒カ洧漫性二存在スル事ガ制ル. 肺藏組織カラ新生シテ來ル上皮細胞 八腎臟絊織カラノモノニ較べテソノ原形質八遙二明イ。

結蟐織母綝胞八放射狀 =發育シ, ソノ形八通常紡錘形デ突起 締織母細胞下吻合シテ居れ，核八楕圓形デ略々細胞體，中央二位シ, ソノ內 $=2$ 個ノ核小體 ガアル.

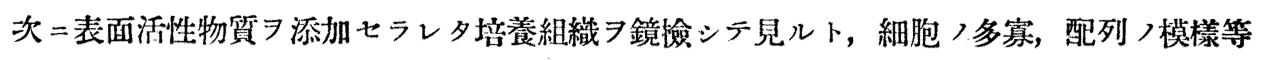

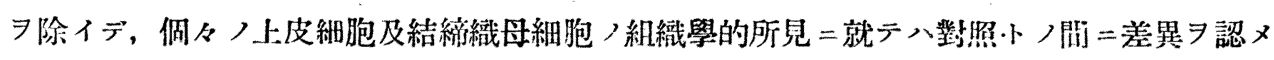
ナカツタ、細胞ノ多寡=就テハ前項デ述ベタガ, ソノ配列二就テハ次ノ培地液化ノ項デ記载 
ル豫定デアル。

\section{3 培地液化 $=$ 就}

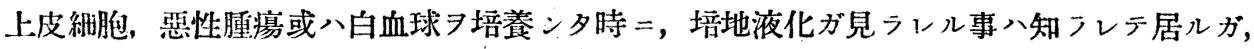
私八荮二上皮細胞培養ノ時ノ培地液化二就テ私ガ觀察シタ所二就テ記载シテ見ヤウト思フ。

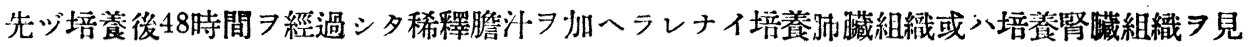
ルト, ソノ牛數近ク二於テ著明ナ培地液化 7 見ル. 著明ナト言ツタガソ八程度八屢々原組織 ’大サョリモ遥二大キナ液化けレタ培地ヨ見ルノデアル。ソシテ液化サレタ培地八必ズ新生 細胞ガ圍マレテ居儿. 私入始メWeigert 氏繊維素染色法デ培地シ形成シデ居儿繊維素习紫 色二染色シ，ソノ染色シナイ部位ヨ搜シテ之ヨ培地液化 7 來シタ場所トシタガ, 培地ノ液化. シタ時ハ殆ンド例外トシニ液化部ハ新生細胞デ圍繞サレテ居ル事ヨ知ツタ. 故二新生細胞=

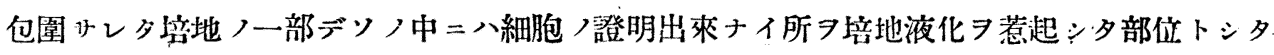
ノデアル．但シ液化シタ培地ノ中二變性二陷ツ夕細胞一一主トシテ圓形細胞デノルガ—ガ 落チ込ンデ居ル事モアルガ，コンナ場合ハ一見シテ區別デキル・ソシテ培地液化八常二圆形 又ハ類圆形ニナツテ起ルモノデ，地圖状又八金平糖状ノ形二起ル事八見ラレナイ．2 個以上

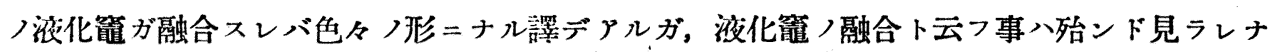
イノデアル. 私ハコノ液化サレタ培地ノ投射面積ヨ上述ノ成長計測ノ時卜同樣 $=$ Edinger's Vertikalprojektionsapparat トPlanimeter デ測定シテソノ值ヨ同樣ニシテ測定シタ原組織偭 積デ除シ, 更ニソ, 本均值

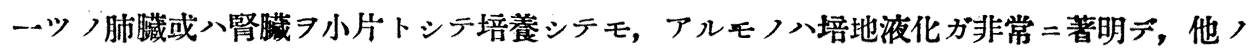
モノ八餘リ著明デハナイ・ソシテ培地液化ノ著明ナモノデハ新生細胞ノ䋁育ハ少ク新生細胞 ノ發育ガ豊筧ナモノデハ培地液化ガ少イ事ヨ知ツタ。

所謂結締織母細胞純唔養ヤ培養心臟組織デハ一般＝培地液化

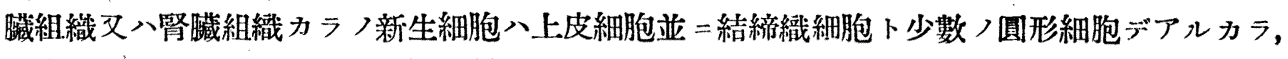
コノ培地液化ハ一見新生上皮細胞ノ作用ノ如ク見エルガ, 上皮細胞發育ノ程度卜培地液化； 程度トハ平行シナイデ寧口反比例スル事カラ考へルト培地液化,罪 モ, 困難ノ樣二思ハレケ來ル。

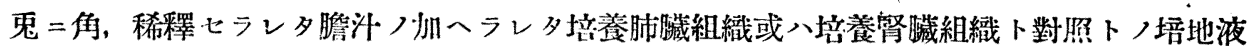
化ノ程度 化ノ程度が輕イノデアル. コノ事入Katzenstein u. Knake モ言及シテ居ナイ事デアル。 


小 南 吉 男 进

以上ノ私 /實驗成績ヨ綜合スレバ, 表面活性物質ノーデアル稀釋セラレタ膽汁ヨ添加サレ

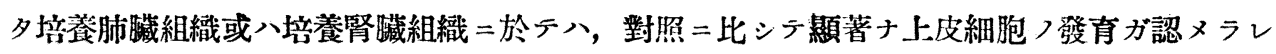
ル. 即千表面活性物質八上皮細胞,坦殖ヨ促スノデアル：從ツテ間接的デハアルガ, 體液, 表面張力低下ガ癌ノ發生原因デアルトイフ說ノ支持點トナルデアラウ・ソシテ稀釋セラレタ

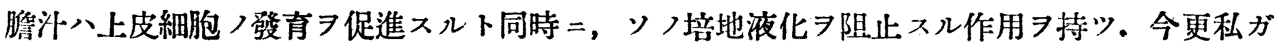
茲デ言フ迄モナイ事デアルガ, 膽汁酸, 性ほるもん，及びたみん等卜或ル種ノ造癌物質 (Karzinogenetische Substanz) ト八關係八近來, 化學的二, 叉八生理的作用二於分注目七ラ レテ居ル所デアル.

Katzenstein，Knake，及 Tranbe $(14,17,18,19,20,21)$ 八培養膵膕組織＝表面活性物質

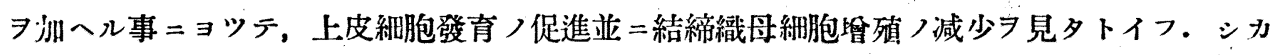
シ私ノ場合二八結締織母細胞〉發育二八餘玅化入認メラレナカツタ・ソノ上氏等八上皮性 細胞, 發育 $\ni$ 促シ・結締織母細胞ノ成長

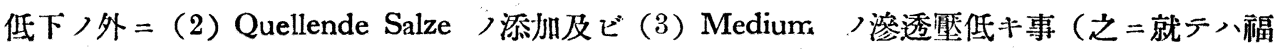

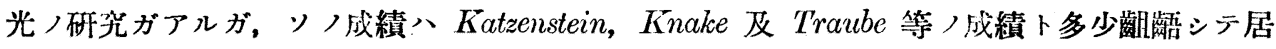

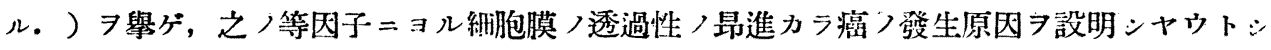
テ居ル.

\section{第 5 童 結論}

或ル種 ノ表面活性物質八培養組織ニ於テソノ上皮細胞ノ發有

（終二臨ミ恩師岡林教授，木村教授〉御懇篤ナル御指導御校閱习深謝シ，併七テ抽木教授 つ御教示 $习$ 謝ス又本研究二際シテノ塚本守久學士ノ御助言习感謝ス).

\section{文献}

1) Bauer. Theoretische u. Erperimentelle Untersuchungen über die Entstehungsbeding ungen des Carcinoms. Zugleich ein Beitrag zur Frage des Konstitutionellen Momentes. Z. f. Krebsforsch. B. d. 20, S. 358.2 2) Kagan. Über die Oberflächenspannung in Extrakte n aus malignen Tumoren Z. f. Krebsforsch. Bd. 21. S. $454 . \quad 3)$ Kagan. Der Einflutz der Künstlichen Oberflächenspannungserniederung auf das Wachstum transplantabler Ca rcinome. Z. f. Krebsforsch. Bd. 21. S. $453 . \quad$ 4) Solowiew. Die bösartigen geschwul ste und bie Oberflächenspannung $\mathrm{de}_{3} \mathrm{~S}_{3}$ erum 3 Gravider u. Krebskranker Z. f. Krebsorsch. Bb. 22. S. 265.6 6) Kapazewski. La tension superficielle et le probleme du cancer C des séiences l'acad, des sciences 179. P. $1445 . \quad 7)$ Roffo u. Degiorji. Ref. aus. Z. f. Krebsforsch. Bd. $23 . \quad$ 8) Guthmann. u. F rühaut. Beiträg zum Carcinomproḅlem Arch, f. gyräk Bd, 134. S. 425. 9) Rabiner, Ref.aus Z. f. Krebsforsch. Bd, 
29. S. 106. 10）荒川, 腫㔠卜表面張力, 近畿婦人科學會雜誌, 9卷, 41頁. 11) 飯

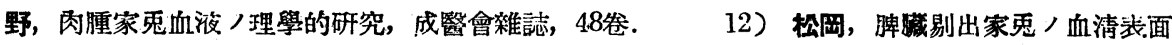

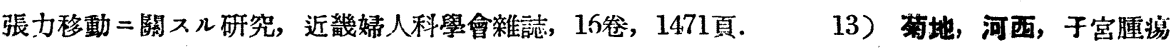
組織 /表面張力, 近畿婦人科學會䆶誌. 18替, 713頁. 14 ) Katzenstein u. Knake.

Die Auregung des Epitbelwachstums bei gleichzeitiger Sstörung des Bindegwebswachstums durch oberflächenactice Stoffe in gewebekuIturen Z. f. Krebsforsch. Bd. 33. S. 378.

15) Fischer u. Laser Studien über Sarkomzellen in vitro V Uber Phagozytosevon Zellen des Rous' Sarkcm und von Fibrcb'asten in vitro A. f. exp. zeelforsch. Bd. 3. $S^{\prime} .363$.

16) 辻. 所謂ふ心ふろぷらすて亿ノ純培養二關ス几知見補遣, 日本微生物學病理學雜誌, 29卷, 375面. 17) Traube. Careinom. Pflanzenwcchatum. Oberflächeuspannungund Permiabiiltät Z. f. Krebsforsch.Bd. 28. S. 356. 18) Knake Über die Wirkungder Veränderung des osmotischen Drucks untersucht an gewebekulturen Asch f. exp. Zellforsch. Bd. 14. S. 611. 19) Knáke Die Wirkung der Hofmeister Spiro'schen. Reihe der. Anionen und Kationen wasser lösliche Salze auf Gewebekulturen. Arsh f. experiment. Zellforsch. Bd. 14. S. 616. 20) Traube u. Knake Über die Regurierung des Washstumgleichgewichte 3 von Epithels und Bindgewebe durch Faktosen nelche die Zellmemb anpe miabilität erhöhen, und ihre Bedeutung für das Krebıprublem Z. f. Krebsforsch. Bd. 42. S. 324.

21) Knake Über die Bedeutung des Permiabilität für das Gewebswashstum Z. f. Krebsf orsch. Bd. 42. S. 329.

22) 木村. 單行本, 組織培養/研究. 


\section{小南論交附圖}
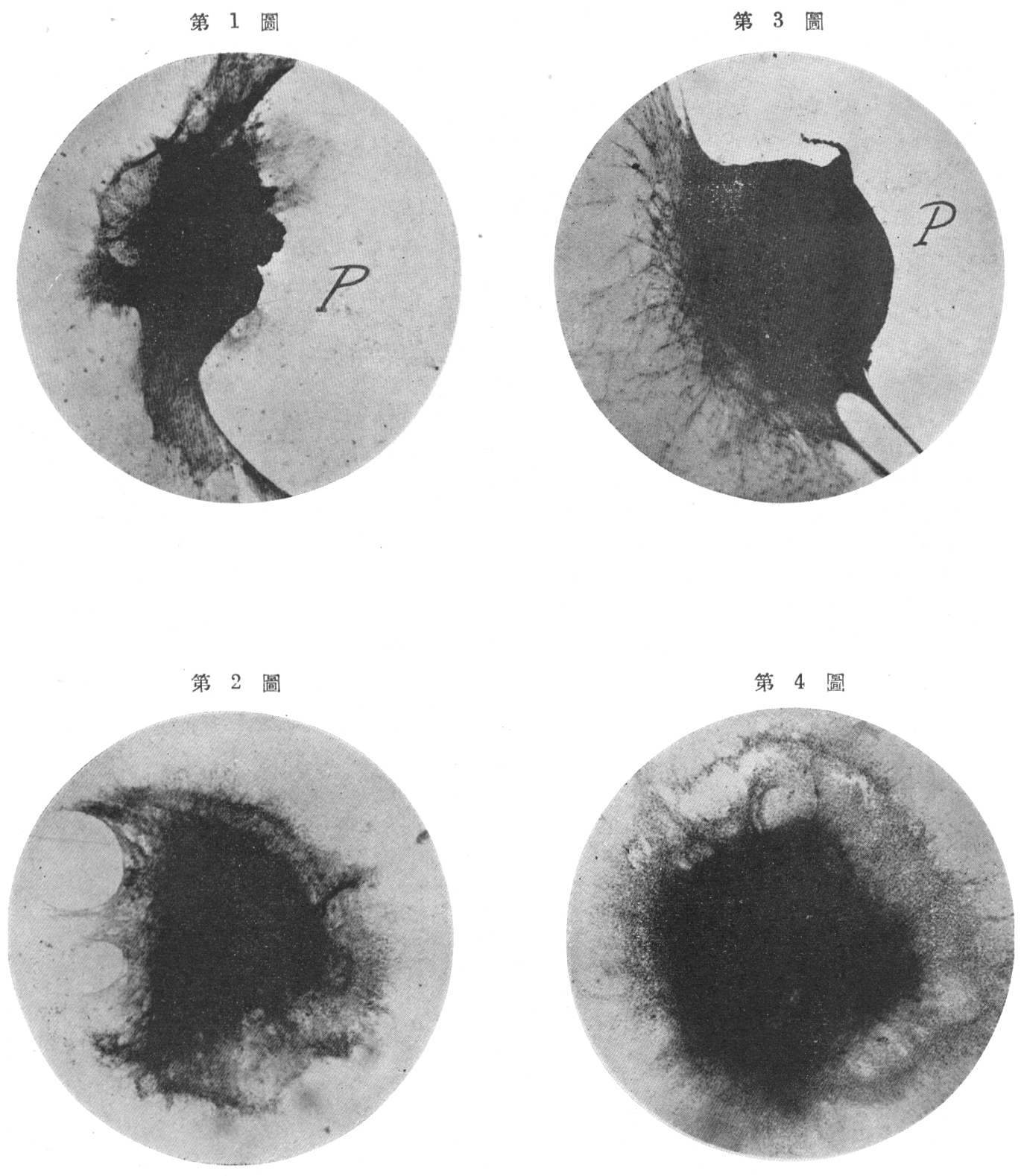
(1305)

\section{附 圖 說 明}

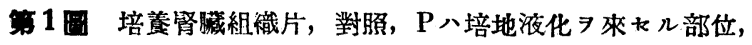

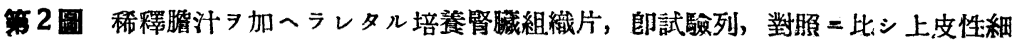
胞ノ增徝著明ニシテ培地液化僅少ナリ。

第 3 圆培養肺㽣組織片, 對炤, $\mathrm{P}$ 八培地液化 7 來七几部位

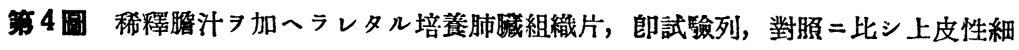
胞 /增殖著明ニシテ培地液化僅少ナリ。

以、上ハ全テ典型的ナル標本ニジテ，培飱後48時間經過七れモノョへまときしりんこ テ染色セれモノナリ。 